\title{
The Future of the Sinai Peninsula
}

\author{
Ruben Tuitel ${ }^{*}$
}

\section{Introduction}

The Sinai Peninsula has been a center of conflict for many years, starting with the first Arab-Israeli war in 1948. After Israel and Egypt signed the Camp David Accords in 1978, it became a peaceful region, strongly controlled by the military during Hosni Mubarak's rule in Cairo. Now, after several years of non-violence, the Sinai Peninsula is once again the center of a complicated conflict. Heavy protests across Egypt in 2011 forced Hosni Mubarak to step down from the presidency, creating a security vacuum in the Sinai that allowed radical Islamists to almost freely operate in the region. During the months that followed, insurgent groups grew in number, recruiting frustrated Bedouin who have been neglected by the Egyptian government for years.

It seems that the Sinai continues to be an area of conflict, but what about the future? Is it possible to achieve peace and stability in this region? This article describes and analyzes the past and present of the Sinai Peninsula, and projects three future scenarios.

The first part will describe past conflicts in order to give an overview of what happened in the Sinai over the past sixty years, starting with the first Arab-Israeli war in 1948 and extending to the peace treaty between Israel and Egypt in 1979 and beyond. The second part will discuss recent and current events beginning with the Arab Spring through the time of this article's writing (December 2013). Then, the final section will present three possible future scenarios based on past and present events.

\section{Background: The Past}

To understand the present situation in the Sinai Peninsula, it is important to understand how we got here. The conflicts between Arab nations in the Middle East (mainly Egypt) and Israel between 1948 and 1978, and the attacks in South Sinai from 2004 to 2006, will be discussed in the following section.

\section{8-1979: Historic Wars}

From 1948 to 1978, several wars were fought between Arab nations and Israel that took place largely in the Sinai Peninsula. These wars obviously had an impact on life in the Sinai Peninsula itself, but they also significantly influenced the political landscape in the Middle East.

The first war was fought in 1948, after the establishment of the state of Israel on 14 May 1948. The Arab nations in the region strongly resented the establishment of the Jewish state and the displacement of the Palestinian population, and launched an attack

* Ruben Tuitel is a Safety and Security Management undergraduate student at The Hague University of Applied Sciences and wrote this paper during his time as a research associate at the PfP Consortium in 2013. 
on Israel one day later on 15 May 1948. However, due to a disorganized command structure on the Arab side, Israel was able to fend off the attack and force the Arab troops to withdraw. The war was fought on many fronts-Jerusalem, the Negev, and the Sea of Galilee were heavily contested areas_-but the Sinai Peninsula was the main theater of the conflict. The second large war between Israel and its Arab neighbors was in 1958, the Suez Crisis. ${ }^{1}$ Then, nine years later, the third large war was fought in the region, known as the Six Day War. ${ }^{2}$ The final war was fought in 1973, when Arab nations invaded Israel on the holiest Jewish holiday, Yom Kippur. ${ }^{3}$ The Suez Crisis marked the end of imperial influence in the Middle East for two European countries: France and Great Britain. The Six Day War and the Yom Kippur War showed that Israel, a small and new state, had achieved military superiority over the much larger Arab nations, who were deeply humiliated by their repeated defeats at Israel's hands (especially Egypt). In 1978 Israel and Egypt signed the Camp David Accords, which concluded a long period of conflict between the two nations.

\section{8: The Camp David Accords}

The Camp David Accords were signed by Egyptian President Anwar Sadat and Israeli Prime Minister Menachem Begin on 17 September 1978. President Jimmy Carter of the United States played an important role during the peace talks, negotiating the terms between Sadat and Begin. After thirteen days of intense negotiations, an agreement was finally reached and signed.

There are two Camp David agreements: "A Framework for Peace in the Middle East" and "A Framework for the Conclusion of a Peace Treaty between Egypt and Israel." 4 The first framework was rejected by the United Nations because the agreement was concluded without participation of the UN, and the Palestine Liberation Organization (PLO) did not agree with some of the terms. The second framework eventually led to the Israel-Egypt Peace Treaty, which was signed in March 1979 and decided the future of the Sinai Peninsula. The Sinai was returned to Egypt by Israel, which withdrew

U.S. Department of State, "Milestones: 1953-1960, Suez Crisis 1956"; available at http://history.state.gov/milestones/1953-1960/Suez. See also Roel Frakking, "The British Colonial Reflex: Eden, Nasser and the Suez Crisis," unpublished university paper (n.d.); available at http://www.academia.edu/1328049/_University_Paper_The_British_Colonial_ Reflex_Eden_Nasser_and_the_Suez_Crisis_1956. And Donald Neff, Warriors at Suez: Eisenhower Takes America into the Middle East (New York: Simon and Schuster, 1981).

2 U.S. Department of State, "Milestones: 1961-1968, Arab-Israeli War of 1967"; available at http://history.state.gov/milestones/1961-1968/ArabIsraeliWar67. See also Avi Shlaim, The 1967 Arab-Israeli War: Origins and Consequences (New York: Cambridge University Press, 2012).

3 U.S. Department of State, "Milestones: 1969-1976. The 1973 Arab-Israeli War"; available at http://history.state.gov/milestones/1969-1976/arab-israeli-war-1973.

4 The full text of both framework agreements is available at http://www.jimmycarterlibrary.gov/ documents/campdavid/index.phtml. 
its armed forces and evacuated inhabitants from the area in return for normal diplomatic relations. The Sinai was then divided into four zones to ensure maximum security:

- Zone A, controlled by the Egyptian armed forces

- Zone $B$, controlled by a maximum of 4000 Egyptian forces

- Zone $C$, mainly controlled by $\mathrm{UN}$ forces, the Multinational Force and Observers (MFO)

- Zone $D$, controlled by a small number of Israeli forces. ${ }^{5}$

The treaty is still in effect. However, while the treaty has not been violated, October 2004 saw violence return to the Sinai.

\section{4-2006: The Sinai Bombings}

On 7 October 2004, a large car bomb destroyed the Taba Hilton hotel in the South Sinai, located on the Egyptian-Israeli border. Later that night two smaller bombs went off at tourist campsites nearby. In total, thirty were killed and hundreds wounded. ${ }^{6}$ On 23 July 2005 , seventy people died when two truck bombs and a suitcase bomb went off in Sharm el-Sheikh. ${ }^{7}$ On 14 August 2005, two roadside bombs hit a passing bus belonging to the Multinational Force and Observers (MFO) in North Sinai. Two Canadians were slightly injured. ${ }^{8}$ On 24 April 2006, Dahab, a seaside resort in South Sinai, was hit by three bombs, killing nineteen and injuring nearly ninety Egyptians and foreign tourists. Two days later, the MFO was hit again, but there were no casualties. ${ }^{9}$

The attacks in Taba, Sharm el-Sheikh, and Dahab — all located in South Sinai-were similar in method: car bombs were used against civilians. The Egyptian and Israeli governments quickly blamed Al Qaeda for the attacks, but the actual perpetrator was unidentified. After an investigation, Egyptian authorities announced that the attacks were carried out by a previously unknown Egyptian group, Tawhid wa Jihad. According to statements from suspects, the group's members include Bedouin and men of Palestinian origin from North Sinai. Later it became clear that the terrorist attacks were part of a larger problem that had been present in the region for several years, stemming from government neglect of the Sinai and its local inhabitants, the Bedouin.

5 "Peace Treaty between The State of Israel and the Arab Republic of Egypt," signed in Washington, D.C., 26 March 1979; available at http://unispal.un.org/unispal.nsf/0/3a159c 13d5084c1085256ced00746faa?OpenDocument.

6 Human Rights Watch, Egypt: Mass Arrests and Torture in Sinai (New York: Human Rights Watch, 2005), 1.

7 International Crisis Group, Egypt's Sinai Question (Cairo/Brussels: International Crisis Group, 2007), 1.

Ibid.

9 Ibid. 


\section{The Sinai and the Bedouin}

The total population of the Sinai Peninsula is currently estimated at 600,000 ; of this number, approximately 200,000 call themselves Bedouin. There are about thirty distinct Bedouin tribes in the Sinai. ${ }^{10}$ Most of the Bedouin are farmers, fishermen, traders, civil servants, tourist guides, and hotel owners. The nomadic and pastoralist lifestyle traditionally associated with the Bedouin nowadays belongs to only a small group of often poor Bedouin. The term "Bedouin" is no longer held to describe a specific way of life, but in terms of belonging to a specific group. ${ }^{11}$

After the Israelis retreated from the Sinai, the Egyptian government focused on developing the Sinai as a tourist region. The population started to grow, but very unequal. In 2002, over 300,000 people lived in the North Sinai, compared to only 60,000 in the South. The South, which mainly generates jobs in tourism and private sector industry, is much more developed than the North, which is one of the poorest areas in the region. Sharm el-Sheikh has become a popular tourist resort: in 2002, it recorded more than six million tourist nights. The tourism industry employs about 12 percent of Egypt's workforce, providing revenues of nearly USD 11 billion in 2009. ${ }^{12}$ The standard of living here is high, comparable to Europe. Over the years, the town was transformed into a modern tourist destination, and most local Bedouin were forced to move away, because their land was sold to hotel operators. The Bedouin have always been a part of the Sinai Peninsula, but they had no land rights, only users' privileges. ${ }^{13}$ Sharm el-Sheikh was primarily an elite enclave, and therefore excluded the traditional Bedouin. In 2005, a government plan to build a wall around Sharm el-Sheikh to prevent terrorist attacks was cancelled due to protests by the local community, as it would have separated a Bedouin settlement from the city. ${ }^{14}$ In response, the governor banned the only economic activities in the city that were open to the Bedouin: offering camel rides to tourists, acting as unofficial guides on trips, and holding soirées at night. ${ }^{15}$ Bedouin were no longer allowed to circulate through Sharm el-Sheikh with their camels and offer rides to tourists. Government sales of land to investment groups pushed the local inhabitants out of the tourism

10 Nikolas Kovač and Trista Guertin, Armed Groups in the Sinai Peninsula (Enschede: Civil Military Fusion Centre, 2013), 1.

11 Donald P. Cole, "Where Have the Bedouin gone?" Anthropological Quarterly 76:2 (200): 235-267; cited at 236.

12 Alexander Dziadosz, "Egypt Tourism Numbers to Fall Less than Feared," Reuters (20 October 2009); available at http://www.reuters.com/article/2009/10/20/ozabs-tourism-egyptidAFJOE59J0PG20091020.

13 Yosef Ben-David, "The Bedouin in Israel," Israel Ministry of Foreign Affairs (July 1999); available at http://www.mfa.gov.il/mfa/mfa-archive/1999/pages/the\%20bedouin\%20in\%20 israel.aspx.

14 "Fence to Protect Red Sea Resort," $B B C$ News (18 October 2005); available at http://news.bbc.co.uk/2/hi/middle_east/4354666.stm.

15 International Crisis Group, Egypt's Sinai Question, 14. 
area and eliminated access to their main source of income. ${ }^{16}$ Hotels and restaurants have replaced many Bedouin villages.

The North Sinai, by contrast, has been known for its poverty and slow development. Development plans created for the region were not executed, and inhabitants started to emigrate from the region looking for better opportunities. The tourism industry grew fitfully over the years, but only welcomed some 50,000 tourists during the summer holiday season. Fishing and agriculture remained the primary economic activities in the region, unlike the South, which saw a dramatic increase in private business activity. The Sheikh Zayed region, which is known for its famous olive trees, is home to the only olive oil factory in the region, which is controlled by the Egyptian Army. ${ }^{17}$ Jobs at the factory were assigned to non-locals instead of the Bedouin, again discriminating against the locals in the region.

The Bedouin in the Sinai Peninsula have been ignored by the government for years. Hosni Mubarak's Sinai policy focused on the profitable tourism industry without acknowledging the settlements of the local Bedouins. Bedouin have only limited possibilities for economic survival - they are not allowed to join the army or to hold governmental positions - and the tourism industry has largely been taken over by commercial organizations. Local political institutions are not completely closed to Bedouin, but they are closely monitored. Tribes have been subject to police regulation when it comes to leadership and representation, including the selection of tribal spokesmen, who are empowered to deal with the authorities. ${ }^{18}$ This makes political involvement for the Bedouin very difficult. The conditions for the Bedouin have been harsh, creating an environment ripe for extreme dissent, and possibly even leading to the bombings in the South Sinai from 2004-06.

\section{The Present: Insurgency, Smuggling, and Military Crackdown}

In December 2010 in Tunisia, high unemployment rates, inflation of food prices, rampant corruption, and the lack of basic rights sparked large-scale protests across the country. ${ }^{19}$ When a young Tunisian street vendor named Mohamed Bouazizi set himself on fire after he was humiliated in public and his wares were confiscated by a municipal officer, the anger and violence of the Tunisian protests intensified. Inspired by the unrest in Tunisia, other Arab countries soon followed suit. Across the Middle East citizens began to demonstrate against oppression in their countries. ${ }^{20}$ In most countries, the demon-

16 Ibid., 15.

17 Ibid., 18.

18 Ibid., 23.

19 Sarah El-Rashidi, "Morsi's Failures in Sinai: A Cautionary Tale," EgyptSource blog, on the Atlantic Council website (4 September 2013); available at http://www.atlanticcouncil.org/ blogs/egyptsource/morsi-s-failures-in-sinai-a-cautionary-tale.

20 The countries that experienced some form of unrest during the Arab Spring include Morocco, Western Sahara, Mauritania, Mali, Algeria, Tunisia, Libya, Egypt, Sudan, Syria, Iraq, Jordan, Saudi Arabia, Yemen, Djibouti, Oman, Bahrain, Kuwait, Iran, Lebanon, and Palestine. In addition, minor protests occurred at the Israeli border. 
strations led to governmental changes, although only few experienced severe clashes of violence, as in Syria, where a civil war is still ongoing. The governments of Libya, Tunisia, Yemen, and Egypt were all overthrown.

Hosni Mubarak became President of Egypt after his predecessor Anwar Sadat was assassinated in 1981. During Mubarak's presidency, political corruption rose dramatically, and some 30,000 people were imprisoned for their political views in a two-year span alone (from 1992 to 1994). ${ }^{21}$ Protests erupted in Egypt in January 2011, focused on Tahrir Square in Cairo, demanding the resignation of Mubarak. He eventually resigned on 11 February 2011, handing over power to the Egyptian Army. As the government focused on economic and political issues in the rest of the country, the Sinai again took a back seat. In November 2011, Egypt held its first parliamentary election since the previous regime. On 24 June 2012, Mohamed Morsi-an Islamist leader of the Muslim Brotherhood-was elected, and people were hopeful that his taking office meant that stability would return to the Sinai. Morsi campaigned on five major issues-security, traffic, fuel, bread, and sanitation - and promised that the Sinai would receive funding as well. ${ }^{22}$ A journalist in El-Arish explained: "Morsi's campaign promised that Sinai would be one of the four pillars of his Nahda program, and thus would receive a quarter of its spending on development and investments." 23

One year later, none of these promises were realized. Most of the Sinai remains without basic services such as clean water, quality health care, and education. Morsi also promised to alter the discriminatory treatment of the local Bedouin and to investigate and review cases of Bedouin who were tried in absentia. None of this has been accomplished, which has led to even more frustration among Sinai's inhabitants. In the end, nothing changed for the Sinai after the toppling of the Mubarak regime.

In fact, the situation worsened when radical Islamists effectively took over large portions of the Sinai and began operating there without much resistance, as early as 2011. Large deliveries of heavy weaponry found their way into the peninsula and into extremists' hands; these groups then targeted both the Egyptian military and installations on the Israeli border. Mubarak's regime had been able to keep any militant groups out of the Sinai for years by employing a zero tolerance approach, which was one of Egypt's treaty obligations as agreed upon in the Camp David Accords. Morsi, on the other hand, refused to employ the same heavy-handed tactics to stop the flow of arms coming into the Sinai, ${ }^{24}$ and his seeming disinterest in stopping the attacks on military personnel and avenging the deaths of Egyptian soldiers displeased the military. The military interpreted this as evidence of his divided loyalties between Islamist groups and his obligation as

21 R. Clemente Holder, Washington Report Archives 1994-1999 (August 1994); available at www.wrmea.org/wrmea-archives/156-washington-report-archives-1994-1999/july-august1994/7540-human-rights.html.

22

23

24 Sahar Aziz, “Sinai's Role in Morsi's Ouster," Sada: Middle East Analysis (20 August 2013); available at http://carnegieendowment.org/sada/2013/08/20/sinai-s-role-in-morsi-s-ouster/gjdr. 
president to preserve security in Sinai. ${ }^{25}$ His soft tactics and the deteriorating situation in the Sinai (and other political issues) eventually led to a coup d'état by the Egyptian Army, who ousted Morsi from his presidency in July 2013.

\section{Insurgency}

After Mubarak's removal from power in 2011, the Sinai Peninsula became a lawless region, creating a security vacuum in the area. The government was more concerned with resolving the country's economic and political problems than safeguarding the Sinai. This allowed radical militants to operate freely in the area.

The very first sign of terrorist activity appeared in July 2011, when a group of tribesmen attacked a police station near El-Arish, the largest town in North Sinai. Three civilians and two police officers were killed, and more were wounded. ${ }^{26}$ On July 30 , a natural gas pipeline was attacked for the third time that month, and for the fifth time in a year. On August 2, a pamphlet with the title "A Statement from Al Qaeda in the Sinai Peninsula" was spread throughout El-Arish, calling for the creation of an Islamic Emirate in the Sinai, an end to the discrimination against the Bedouin, and an end to the exploitation of Sinai's wealth by non-residents. ${ }^{27}$ Since then, the Sinai has seen a sharp increase in terrorist activity, and the government's inability to enforce the rule of law has been heavily exploited by these terrorists. The state police tried to address this instability through violent means. According to Sheikh Ahmed El-Herish of the Qararsha tribe, "The police department insists on destroying everything we do and will eventually destroy Egypt," in part because of a desire to take revenge for what happened during the Arab Spring. ${ }^{28}$ Subsequently, frustrated Bedouin have joined radical Islamist groups, seeking retribution for the neglect and violence they have suffered at the hands of the Egyptian state.

At present, the Sinai is home to multiple armed groups, but it remains unclear how many militants are actually in the area. Western intelligence agencies report the existence of several dozen militant bases with fifteen to twenty members each. ${ }^{29}$ According to the Israeli military, a common trait of all the militant groups in the Sinai is a link to Gaza; most of the Sinai-based groups are believed to be offshoots of Gaza terror groups.

25 Ibid.

26 Andrew McGregor, "Hot Issue - Has Al-Qaeda Opened A New Chapter in the Sinai Peninsula?" Jamestown Foundation (1 August 2011); available at www.jamestown.org/single/?no cache $=1 \&$ tx_ttnews $\% 5$ Btt_news $\% 5 \mathrm{D}=38332$.

27 Ibid.

28 Mohannad Sabry, "Under Mubarak, Morsi or Sisi, Sinai Remains a Victim," EgyptSource blog (7 August 2013); available at http://www.atlanticcouncil.org/blogs/egyptsource/undermubarak-morsi-or-sisi-sinai-remains-a-victim.

Nikolas Kovač and Trista Guertin, Armed Groups in the Sinai Peninsula (Enschede: Civil Military Fusion Centre, 2013). 
Reports indicate the terror groups have growing ties with the local Bedouin who give them refuge and provide escape routes. ${ }^{30}$ The following armed groups are known to be active in the Sinai or have some kind of influence: ${ }^{31}$

- Ansar Bayt al Maqdis (Supporters of Jerusalem): This terrorist group is considered the most active group in the Sinai. It consists primarily of Sinai Bedouin, but also has members from other Middle Eastern countries and North Africa. It is believed to have approximately 2,000 members.

- Hamas: The Palestinian organization is probably the best-known terrorist organization in Gaza and is responsible for many terrorist attacks.

- Jaish al Islam (Army of Islam): Also a terrorist group in Gaza. Its activities include individual terrorist actions and kidnappings. Due to clashes with Hamas, its influence has decreased.

- Takfir Wal Hijra (Anathema and Exile): Founded in 1969, this group is one of the oldest active in Egypt. It is a loosely organized group that has ties with $\mathrm{Al}$ Qaeda and defies customs of tribal law, which makes it unpopular among the Bedouin.

- Tawhid al Jihad: Similar to Jaish al Islam, Tawhid al Jihad is an organization based in Gaza that is also active in the Sinai. The group is responsible for the bombings in 2004-06. The cell uses the Northern Sinai mountains as its headquarters. It actively carries out bombings, armed attacks, and kidnappings against Israeli and Western workers and tourists and is rumoured to have around 1,200 members.

- The Mujahedeen Council of Shura in Environs of Jerusalem: This organization regards itself as a coordinator between several Gaza/Sinai jihadist groups, including Tawhid al Jihad. It opposes a peace treaty with Israel and targets Israeli positions.

- Jund al Sharia: The group issued a list of five demands to the Egyptian and U.S. governments. The demands include the introduction of Islamic Law into Egypt and the release of all Muslim prisoners.

- Ansar al Jihad: This is the newest group in the Sinai, and has pledged allegiance to Al Qaeda and its leader Ayman al-Zawahiri. It announced its existence in late 2011, and claimed responsibility for the attacks on Egypt's natural gas pipeline in July and August 2011. It has not been much in the news since, which leads to questions about the group's actual significance.

The many groups active in the Sinai make it difficult for the Egyptian authorities to respond to the insurgency. The response is also limited by the Camp David Accords from 1979, which are still in effect. As mentioned above, the Egyptian military has

\footnotetext{
30 Kovač and Guertin, Armed Groups in the Sinai Peninsula.

31 Ibid.
} 
troops stationed in Zone A and B. Zone C is controlled by the Multinational Force and Observers, and Zone D is occupied by some 4,000 Israeli troops. Responding to the insurgency might compromise the relationship between Egypt and Israel and violate the terms of the Camp David Accords. Despite this, Egypt launched a campaign called "Operation Sinai" in August 2012 to eliminate the Sinai insurgency. The operation was launched after a large attack on the Egyptian-Israeli border that killed sixteen Egyptian soldiers. ${ }^{32}$ During the month, the Egyptian military launched several attacks on militants in the Sinai, killing and arresting several of them. The military called the operation a great success. ${ }^{33}$ However, according to Bedouin activists, it was nothing more than a media stunt: "Operation Eagle was a failure; the majority of the tunnels are still operating. With the new development projects in Gaza, the need for them has grown, and this has increased strife...." 34

Recent reports contradict this, indicating that attacks by jihadist groups are on the decline. "Operation Sinai" is still ongoing. Recently, Ansar Bayt al Maqdis reported that three of its members were killed in clashes with the Egyptian Army, ${ }^{36}$ confirming the activity of Egyptian security forces in the Peninsula. Statements like the above by Bedouin activists are most likely media stunts themselves, encouraging others to fight against the Egyptian authorities. Some of the insurgent groups (but also some non-extremist Bedouin) are also involved in smuggling, adding to the complexity of the problem in the Sinai.

\section{Smuggling}

The possibilities for economic survival for Bedouin in the Sinai are scarce. They are not allowed to own property, enter politics, join the army, or hold any government post. The land they "own" to grow crops can be taken away by the government. Some of the Bedouin have therefore resorted to smuggling in order to survive. Using a large underground tunnel network, smugglers bring food or weapons across the border into Gaza. Heavy

32 On 5 August 2012, armed men ambushed an Egyptian military base in the Sinai, killing sixteen soldiers and stealing two armored cars, which they used to infiltrate Israel. Israeli Defense Forces engaged in a firefight with the attackers, killing seven. "Egyptian Border Guards Killed in Sinai Attack," Al Jazeera (5 August 2012); available at www.aljazeera.com/ news/middleeast/2012/08/201285183958163902.html.

33 "Egyptian Army Declares Success in Crackdown on Sinai Terrorists," Times of Israel (8 August 2012); available at http://www.timesofisrael.com/egyptian-military-fires-missiles-atsuspected-islamist-terrorists-in-sinai/.

34 El-Rashidi, "Morsi's Failures in Sinai."

35 Jamie Dettmer, "Egypt's Military: Sinai Jihadist Attacks on the Decline," Voice of America (6 November 2013); available at www.voanews.com/content/egypts-military-sinai-jihadistattacks-on-the-decline-/1784743.html.

36 David Barnett, "Ansar Jerusalem Announces Deaths of 3 Fighters, Including Commander," Threat Matrix (2 December 2013); available at http://www.longwarjournal.org/threatmatrix/archives/2013/12/ansar_jerusalem_announces_deat.php. 
weaponry smuggled in from Libya is used against Egyptian forces or passed along to Gaza. $^{37}$

\section{Military Crackdown}

On 8 July 2013, after Morsi was ousted from the presidency, the Egyptian military and the Republican Guard clashed with pro-Morsi and Muslim Brotherhood protesters in Cairo. The Egyptian military claimed that protesters tried to attack the building of the Republican Guards. The military responded by shooting teargas and live ammunition at the protesters, eventually killing almost sixty people. ${ }^{38}$ On August 14, the military attacked two Cairo encampments of Morsi protesters. Nearly 250 people were killed in the incident. ${ }^{39}$ The assault followed after the Muslim Brotherhood called on Egyptians to rise up in protest. Supporters started throwing stones and firebombs at security forces. The violence between Muslim Brotherhood supporters and the military has continued, and began to take civil war-like form, heavily affecting Egypt's political and economic system but also the rest of the Arab world.

\section{The Future: Three Scenarios}

The situation in the Sinai Peninsula is made even more complicated by the Egyptian government's exclusive focus on political and economic issues instead of addressing one of the most important areas of its territory. This gives militants the opportunity to operate freely, making Sinai a breeding ground for terrorists in an already extremely volatile area between Egypt and Israel. The question is, What will the future of the Sinai look like? This section will describe three scenarios based on past and present events.

\section{Scenario 1}

One positive scenario could be that the military is able to stabilize the situation with respect to the Muslim Brotherhood, and will be able to avoid further violence. Since the government was successful in reducing the level of jihadist attacks in the Sinai, this scenario is not impossible. Should this come to pass, the military (under pressure from the international community) could resort to more peaceful means and slowly but surely allow more rights for the population overall. Democratic elections would be held in a peaceful atmosphere, increasing the chance for honest outcomes. The newly elected president would learn from the mistakes of his predecessors and follow a more moderate

37 Gili Cohen, "Sinai Peacekeeping Force Commander Warns of Weapons Smuggling to Gaza," Haaretz (31 May 2012); available at http://www.haaretz.com/news/diplomacy-defense/sinaipeacekeeping-force-commander-warns-of-weapons-smuggling-to-gaza-1.433567.

38 Patrick Kingsley, "Killing in Cairo: The Full Story of the Republican Guards' Club Shootings" (18 July 2013); available at http://www.theguardian.com/world/interactive/2013/ jul/18/cairo-republican-guard-shooting-full-story.

39 Mayy El Sheikh and Alan Cowell, "Hundreds Die as Egyptian Forces Attack Islamist Protesters," New York Times (14 August 2013); available at http://www.nytimes.com/2013/ 08/15/world/middleeast/egypt.html?pagewanted $=2 \& \_r=0$. 
political approach. The president would make sure government funds are allocated to the Sinai to start new development projects. The voice of the Bedouin would be heard again; they would gain more rights, and be allowed to own land. They could hold jobs not currently available to them. The insurgency would lose support, and the number of radical militants could be greatly reduced. It is likely that international relations would improve and exports and imports would start to grow, which would improve the nation's economy. This scenario would be a positive change for the Sinai and Egypt as a whole. For the more distant future, this would mean that Egypt would become a stable and perhaps a democratic country. It could also serve as an example for other Middle Eastern countries, perhaps encouraging them to change as well. This would be a slow process, and could take many years before it becomes reality.

\section{Scenario 2}

A scenario that stands between the positive and negative scenarios is if the powerful General Sisi is elected as president. At the moment, General Sisi is quite popular in Egypt, despite his actions against Muslim Brotherhood supporters. Speculation holds that Sisi will garner around 70 percent of the votes if he decides to run for president. ${ }^{40}$ However, General Sisi's military background will probably bring Egypt where it does not want to be in the future. Security in Egypt and the Sinai Peninsula would most likely be restored, and he will gain popularity. However, tight security often affects the freedom of civilians, which is already unbalanced, especially in the Sinai. Egypt could head for a future of military rule where elections are rigged in favor of the military. This scenario might closely resemble the era of Mubarak's rule, in which the Muslim Brotherhood was classified as an illegal party, yet levels of stability and security in Egypt are high. On the other hand, during his presidency, despite his poor human rights record, Mubarak's foreign policy contributed to stability in the Middle East through his support for the Egypt-Israel peace treaty, his resistance to Islamist extremism, his positive role in the Israeli-Palestinian peace process, and his close relationship with the United States. ${ }^{41}$

In this scenario, the overall level of stability in Egypt would increase due to military action against Islamist extremists, but the Sinai might remain a rather neglected area. In the more distant future this would mean that Egypt would continue to be a military power, much like during the Mubarak regime. This has positive and negative aspects. The Sinai would most likely be safer than it is now, as the Islamist extremists would be driven out of the area by the Egyptian Army. The current military campaign aimed at removing radical jihadists from the Sinai bears a strong resemblance to the Mubarak era

40 Abdallah el-Senawi, "Egypt's Big 'what if'? Sisi and his Possible Rise to Power," Al Arabyia Institute for Studies (13 November 2013); available at http://english.alarabiya.net/en/ perspective/alarabiya-studies/2013/11/13/Egypt-s-big-what-if-Sisi-and-his-possible-rise-topower.html.

41 Ghassan Shabaneh, Egypt and Syria's Effect on the Israeli-Palestinian Conflict (Qatar: AlJazeera Center for Studies, 2013). 
and seems to be successful. If General Sisi were to follow a "Mubarak approach," the peace process between Palestine and Israel could also be positively influenced, and overall stability in the region would increase. Another positive aspect is that General Sisi is very nationalistic and is a moderate Islamist. ${ }^{42}$ The chances that Egypt would become an Islamist state are small. A negative side would be that the focus of Egypt's government would primarily be placed on military security, and not so much on political and economic prosperity. This would result in economic inequality and political oppression.

\section{Scenario 3}

In this more negative scenario, a large-scale civil war could erupt in Egypt, with the Sinai a primary conflict zone. At the moment, the Egyptian military is enjoying success in tackling the Sinai insurgency; reports have shown that attacks have actually decreased. However, the Egyptian military and police currently find themselves in a vicious circle of violence on another front. The violence against Muslim Brotherhood supporters in Cairo and the waves of mass arrests are actually strengthening the resolve of insurgent groups throughout Egypt, leading to more resistance from their side, resulting in more violence by the state's security forces, and so on. The Egyptian military would lose control over Egypt's and Sinai's security, and Islamists, whether they are Muslim Brotherhood supporters or not, would continue to fight against military rule. It is likely that when the violence between the military and pro-Brotherhood supporters continues, the insurgency in the Sinai will increase in strength as well. The radical Islamists in the Sinai would be able to continue their operations in the peninsula, making it an even more volatile region. The Bedouin would likely choose the side of the radical Islamists, who would protect the Bedouin in order to gain more popularity. The situation in Sinai may affect other Middle Eastern countries as well, although most of them have already been through a long phase of unrest, and might not be affected at all. Yet it is likely that Israel will be affected by this conflict. With increasing operations from insurgents, including smuggling operations, Gaza-based terrorist groups would grow in strength, resulting in more attacks on Israel's territory. While General Sisi and his supporters ousted Mohamed Morsi to prevent a civil war, the situation is now very precarious and might end up at that point. Concerning the more distant future, Egypt would be focusing on rebuilding its economy and resolving its political chaos, much like it is doing now, leaving the Sinai neglected again. Sinai would become the center of a complicated conflict, and would become an even more important breeding ground for radical Islamists.

\section{Conclusion}

The Sinai has been a conflict zone for many years, and served as a strategic area in the Egypt-Israel wars of the twentieth century. Now it is home to many insurgents and

42 Raymond Stock, "Who Is General al-Sisi and What Will He Do with Egypt?" MissingPeace(20 October 2013); available at http://missingpeace.eu/en/2013/10/who-isgeneral-al-sisi-and-what-will-he-do-with-egypt/. 
represents an area of conflict between Egypt's state security forces and radical Islamist groups. The local Bedouin were neglected for years under the Mubarak administration, and some seek retribution for this by fighting against the military and the police. There was hope in 2011, however, that the situation would change when Mubarak, under heavy pressure by the Egyptian people, decided to step down as president. Democracy and stability came closer to being a reality and, for a while, this seemed to be the direction Egypt was heading. When Mohamed Morsi was chosen as the new president of Egypt, expectations rose; but when he could not deliver on his promises, the military turned against him and removed him from office. Now, Egypt seems to be on the brink of civil war, with violent clashes between the military and pro-Morsi supporters and a widespread insurgency in the Sinai Peninsula. The three future scenarios described are merely an idea of what could happen based on recent and past events. What really will happen depends on the actions of the Egyptian government and the will of the Egyptian people. The security of the Sinai, and the whole stability of the Middle East, depend on the decisions that are made in Cairo. The people of Egypt demanded democracy in 2011, but learned the hard way that democratic decisions are no guarantee for a sustainable democratic development. Egypt has to decide which way it wants to go, maybe back to a Mubarak-like era where, despite human rights violations, security was guaranteed. For now, the people in the Sinai are forced to protect themselves from extremists and the government alike. 


\section{Bibliography}

Aziz, Sahar. Sinai's Role in Morsi's Ouster In Sada: Middle East Analysis., 2013.

Barnett, David. Ansar Jerusalem Announces Deaths of 3 Fighters, Including Commander. Threat Matrix, 2013.

Ben-David, Yosef. The Bedouin in Israel. Israel Ministry of Foreign Affairs, 1999.

Cohen, Gili. Sinai Peacekeeping Force Commander Warns of Weapons Smuggling to Gaza. Haaretz, 2012.

Cole, Donald P.. "Where Have the Bedouin gone?" Anthropological Quarterly 76, no. 2 (2000): 235-267.

Dettmer, Jamie. Egypt's Military: Sinai Jihadist Attacks on the Decline. Voice of America, 2013.

Dziadosz, Alexander. Egypt Tourism Numbers to Fall Less than Feared. Reuters, 2009.

Egypt: Mass Arrests and Torture in Sinai. New York: Human Rights Watch, 2005.

Egypt's Sinai Question. Cairo/Brussels: International Crisis Group, 2007.

Egyptian Army Declares Success in Crackdown on Sinai Terrorists. Times of Israel (2012).

Egyptian Border Guards Killed in Sinai Attack. Al Jazeera, 2012.

El-Rashidi, Sarah. Morsi's Failures in Sinai: A Cautionary Tale. EgyptSource blog, on the Atlantic Council website, 2013.

el-Senawi, Abdallah. Egypt's Big 'what if'? Sisi and his Possible Rise to Power. Al Arabyia Institute for Studies, 2013.

Fence to Protect Red Sea Resort. BBC News, 2005.

Kingsley, Patrick. Killing in Cairo: The Full Story of the Republican Guards' Club Shootings., 2013.

Kovač, Nikolas, and Trista Guertin. Armed Groups in the Sinai Peninsula. Enschede: Civil Military Fusion Centre, 2013.

McGregor, Andrew. Hot Issue - Has Al-Qaeda Opened A New Chapter in the Sinai Peninsula?. Jamestown Foundation, 2011.

Milestones: 1953-1960, Suez Crisis 1956. U.S. Department of State, 2013.

Milestones: 1961-1968, Arab-Israeli War of 1967. U.S. Department of State, 2013.

Milestones: 1969-1976. The 1973 Arab-Israeli War. U.S. Department of State, 2013. 
Neff, Donald. Warriors at Suez: Eisenhower Takes America into the Middle East. New York: Simon and Schuster, 1981.

Peace Treaty between The State of Israel and the Arab Republic of Egypt. Washington, D.C., 1979.

R. Holder, Clemente. Washington Report Archives 1994-1999., 1994.

Sabry, Mohannad. Under Mubarak, Morsi or Sisi, Sinai Remains a Victim. EgyptSource blog, 2013.

Shabaneh, Ghassan. Egypt and Syria's Effect on the Israeli-Palestinian Conflict. Qatar: Al-Jazeera Center for Studies, 2013.

Sheikh, Mayy El, and Alan Cowell. "Hundreds Die as Egyptian Forces Attack Islamist Protesters." New York Times (2013).

Shlaim, Avi. The 1967 Arab-Israeli War: Origins and Consequences. New York: Cambridge University Press, 2012.

Stock, Raymond. Who Is General al-Sisi and What Will He Do with Egypt?. MissingPeace, 2013. 